\title{
Resenha do livro When species meet, de Donna J. Haraway
}

\section{Camila Mangueira'}

É com as perguntas “(I) Quem e o que eu toco quando toco em meu cachorro? e (2) Como ‘tornando-se com’ é uma prática de tornar-se conhecedor do mundo?”2 (p. 3) que a norte americana Donna Haraway (I944) inicia When Species Meet e nos convida a uma prática de curiosidade e de abertura para as experiências, os significados e os mundos possíveis despertos nas relações com os outros seres. Especialmente, mas não somente, com aqueles que partilhamos o cotidiano.

É na simplicidade em que convoca o comum e o mundano que Haraway não apenas tenciona em profundidade a ideia de sujeito humano, mas provoca a ir além. Afinal, como o tornando-se com (becoming with) o outro na mesma terra pode gerar impactos reais na transformação dos sujeitos parceiros com reflexos na cultura e na produção do conhecimento?

Haraway apresenta uma miríade de sujeitos e parceiros emaranhados que não são meramente conceitos ou ideias literárias, mas seres comuns em contato na casa, na rua, no laboratório, no zoológico, no estádio de esportes, no parque, na prisão, no oceano, na fábrica. Seres de significado, os quais a autora, desde as primeiras linhas do livro, faz questão de apresentar e situar.

Os contextos de observação incluem relatos pessoais e profissionais, experiências em campo e participação em conferências acadêmicas e profissionais; a análise de casos situados e históricos despertos nos livros, nos programas televisivos, nas fotografias, websites; a apresentação de documentação de diferentes natureza e origem, dentre elas, artigos científicos, jornais e panfletos, cartas e e-mails. Dentre os seres de possibilidade

I Doutora em Comunicação de Semiótica pela Pontifícia Universidade Católica de São Paulo, Brasil. Atualmente professora assistente convidada do Departamento de Design da Faculdade de Belas Artes da Universidade do Porto, Portugal. Cv-LATTEs: lattes.cnpq.br/I25603637I033952. E-mail: camilamangueira@ gmail.com.

2 (I) Whom and what do I touch when I touch my dog? and (2) How is "becoming with" a practice of becoming worldly? (p. 3) 
imaginada e os de carne e comuns que surgem entre as páginas estão lobos e cães na Síria e nos Alpes franceses, cães clonados, criminosos e cachorros em treinamento na prisão, cães e humanos praticando esporte juntos, tigres de banco de dados, um jornalista esportivo de muletas, baleias com câmeras e muitos outros.

Haraway coloca em ação o seu método de combinar e conectar fatos científicos, histórias e teorias que possibilitam conexões entre o comum, o familiar, o estranho e o desconhecido. Haraway é persistente nas tentativas por aprimorar uma narrativa analítica que possa funcionar na ciência sem ignorar a relação entre fatos e ficções. Claramente que a seriedade de sua prática compreende o diálogo constante com obras e estudos filosóficos e científicos. Entre os teóricos que colaboram para a construção das lentes críticas das multiespécies estão Jacques Derrida, Gregory Bateson, Alfred North Whitehead e Michel Foucault.

Publicado em 2008, o livro compreende pelo menos mais de vinte anos de um criativo trabalho intelectual e cultural de Haraway como bióloga - também com formação em Filosofia e Zoologia -, escritora, estudiosa das humanidades e ciências sociais e docente ${ }^{3}$ de teorias feministas, estudos científicos e animais. A obra faz parte da série Pós-humanidades (Posthumanities), editada pelo pesquisador americano Cary Wolfe, coleção que propõe a intersecção com as mudanças sociais, políticas e culturais apontadas pelos estudos do pós-humanismo crítico.

As seções "Notas" e "Histórico da Publicação" reforçam a predileção de Haraway por exibir suas comunidades de contato e a materialidade do seu pensamento, como também, apresentar os indícios de um trabalho em contínuo progresso. A obra contempla a reescrita de textos e algumas discussões iniciadas em publicações anteriores, dentre elas Primate visions (I989) e The companion species manifesto (2003). Pelo viés das multiespécies, Haraway retoma figuras como o ciborgue 4 (cib-ernético e org-anismo), tratada por ela nos anos 80 em A cyborg manifesto. Contexto em que sua leitura feminista do ciborgue foi fundamental para a origem a uma comunidade de artistas, teóricos e críticos que passaram a compreender a ideia do pós-humano. Vale destacar que, para Haraway (GANE, 2006) o ciborgue e as espécies são abordagens que permitem o questionamento sobre as relacionalidades e que, por esse ângulo, "espécies" é também uma via de conciliação e confronto com a ideia de pós-humano.

3 Desde os anos 8o integra o Departamento de História da Consciência da Universidade da Califórnia em Santa Cruz. Página da autora na Universidade: humanities.ucsc.edu/ academics/faculty/index.php?uid=haraway. Acesso em: 9 ago. 2020.

4 Obra que tornou Haraway mundialmente conhecida ao questionar o papel do corpo no rompimento com ideologias e epistemologias humanistas tradicionais. 
O livro é organizado em três capítulos. No primeiro e mais extenso deles, "Nós nunca fomos humanos", Haraway se dedicada às linhas lógicas, conceituais e discursivas que compõem as espécies companheiras. Haraway parte da percepção de que os discursos que relacionam animais e tecnologias continuam ainda enraizados em antigas premissas ocidentais de separação ${ }^{5}$ entre natureza e cultura. As quais, segundo ela, não oferecem abertura para as reais implicações que estão justamente na relação entre elas. A partir disso, ela questiona o espaço que possa conciliar a atenção e o amor pela natureza orgânica e pela tecnologia, o qual não precise recorrer ao discurso de superioridade do humano sobre o animal. Um espaço em que a figura do ciborgue e do cachorro admitem coexistência mútua.

No sentido dessa visão, Haraway analisa (p. II) as três feridas do narcisismo humano - a copernicana, a darwiniana e a freudiana - e aponta uma quarta: a informática ou ciborguista. Lembra que as três primeiras geraram deslocamentos e separações cosmológicas, zoológicas e psicanalíticas entre o humano e o planeta. A quarta ferida é provocada pela relação com que não é humano, isto é, com o maquínico, com o não-vivente. A qual, segundo ela, nos levam a considerar as relacionalidades constitutivas com eles.

Haraway argumenta que, pela perspectiva do comum e do mundano, grandes divisões como animal e humano, orgânico e técnico se achatam em tipos e consequências que exigem respeito e resposta entre espécies. Respostas multiespécies que não são necessariamente de caráter simétrico ou mimético. Esclarece que o termo "espécies" trata simultaneamente de diversos fluxos culturais e sociais de significado que compreendem desde o lógico, a biologia evolutiva até a especificidade das linguagens tradicionais. Sua proposta de espécies companheiras se concentra basicamente no fato de que animais humanos e não humanos são espécies companheiras (do latim cum panis, p. I7). Isto é, espécies que dividem a "mesa" e que "comem juntas" no jogo das inter e intra-relações constitutivas. Jogo que não oferece garantias de uma "boa digestão".

A autora investiga possíveis efeitos lógicos e práticos de um engajamento científico, biológico, filosófico e íntimo com outras espécies. Em diálogo com Jacques Derrida (p. I9), Haraway questiona os limites na prática de curiosidade pelos animais e na produção discursiva sobre essas experiências. Aponta que o fato de não termos ainda uma tecnologia de escrita para lidar com essas relações não justifica a sua desconsideração.

5 Ver também o questionamento da autora acerca do papel do corpo no rompimento com ideologias e epistemologias humanistas tradicionais em A cyborg manifesto (i985). Nos quais ela critica os discursos de caráter patriarcal e capitalista pautados em grandes divisões: mente e corpo (“físico e não-físico"), animais e humanos, organismos (animal-humano) e máquinas. 
Outro ponto debatido por ela é o sentido de tornando-se com (becoming with) das espécies companheiras. Elucida que não diz respeito (p. 27) à proposição de tornando-se animal (becoming-animal) de Gilles Deleuze e Félix Guattari (I987). Haraway esclarece que a abordagem de "animal" dos autores se baseia numa filosofia do sublime pautada em dicotomias como selvagem e doméstico, lobo e cachorro. Fundamentos que, segundo ela, servem para expressar não apenas o desprezo dos autores pelas "figuras" de carne e mundanas - especialmente as "domésticas" -, mas promover uma excepcionalidade individual.

Em ampliação da perspectiva das espécies companheiras, Haraway investiga o valor das espécies na tecnocultura capitalista no início do século XXI. Com base em Capital v. 1 de Marx (I977), Haraway propõe sua versão Biocapital v. 1 na qual além do valor de uso e o valor de troca, compreende também o valor do encontro (p. 46). A partir disso, discute a caracterização dos sujeitos de diferentes espécies biológicas dentro dos valores vigentes do consumo. Ela mostra como o crescimento do mercado das espécies revela toda uma cultura de produção (alimentos, produtos, serviços para animais, agronegócio e biomedicina científica) na qual cães se tornaram também biotecnologias, trabalhadores (em ambientes públicos e privados) e agentes da produção de conhecimento tecnocientífico. Haraway apresenta também redes multiespécies de valores agregados que não necessariamente são regidos por fins lucrativos. Nesse ponto (p. 6I), exemplifica com o caso sobre os cuidados de cães experimentais, nos quais amostras de tecido e DNA dos animais de estimação tem sido utilizado em pesquisas para localizar genes associados ao câncer em cães e pessoas.

O capítulo inicial também inclui o debate sobre a ética das relações instrumentais com animais (p. 69). Haraway desmitifica o fato de que as pesquisas experimentais com animais não são o problema ao mostrar indícios de que muitas vezes são necessárias e podem ser boas. No entanto, é fundamental que tais práticas não legitimem uma relação de sofrimento num sentido apenas regulatório ou não envolvido e implicado. Através do exame de práticas instrumentais historicamente situadas, Haraway apresenta exemplos de partilhas responsáveis de sofrimento, as quais não recorrem a argumentos de vitimização e de sacrifício. Para isso, destaca a importância de um compartilhamento não mimético multiéspecies, o qual não uniformiza os tipos de respostas dos envolvidos.

No segundo capítulo, "Notas da filha de um jornalista esportivo", Haraway aborda de maneira mais reflexiva as relações próximas e pessoais e a prática nas ciências humanas e sociais. O início (p. I62) é dedicado ao legado do seu pai, Frank Outten Haraway, para o pensamento das 
espécies companheiras. Desde seu falecimento em 2005, Haraway se propôs a reconhecer a traçar os nós dos corpos animados e inanimados que compunham sua vida particular. Aqui a espécie companheira em questão não é ela ou outro organismo, mas as muletas e as cadeiras de rodas de seu pai. Haraway conta que, acometido por paralisia desde a adolescência, foram as próteses que possibilitaram não apenas uma vida comum, mas a participação em jogos e competições como jornalista. Ela comenta que as muletas e as cadeiras de seu pai acabaram por infundir simbioticamente os corpos de toda a família. A autora questiona também as heranças do corpo híbrido e articulado do pai na sua curiosidade pela contínua história das figurações - como, por exemplo, os ciborgues -, dos seres, dos corpos em formação e dos jogos nos quais nem todos os companheiros são humanos. Haraway afirma (p. 165) que possivelmente um dos maiores ensinamentos da existência dele foi o de que nós nunca fomos humanos. Isto é, que nós não estamos presos em visões unilaterais que dividem ator e instrumento, mente e matéria.

Adiante (p. I8I), Haraway apresenta uma série de correspondências que, iniciadas com o intuito de homenagem ao pai, evoluíram em conversas com acadêmicos, mentores caninos, família humana, dentre outros. Questiona sobre como esse híbrido de notas de campo, cartas e entradas de diário pessoal, independente de seus valores acadêmicos, são formas de sociabilidade que acrescentam dados e ajudam nas análises. Para ela são expressões de formas de contágios também fundamentais sobre e para o processo de digressões das espécies companheiras.

A autora aborda também o tema das zonas de contato, nas quais diferentes espécies compartilham as mesmas condições de trabalho. Haraway examina como a prática esportiva conhecida por agility, realizada por ela e sua cadela Cayenne, ${ }^{6}$ alteraram a sua percepção sobre as relações controversas e modernas entre pessoas e cães (p. 205). A partir disso, discute desde os problemas do emprego de pronomes a condutas alternativas de uma educação não autoritária e coercitiva. Haraway ressalta que as formas de comunicação com Cayenne tiveram de ser descobertas a partir do corpo a corpo na zona de contato. Para ela, ideias filosóficas e literárias de que temos apenas representações e nenhum acesso ao que animais pensam e sentem conduz a enganos. Aqui lembra que técnica, cálculo, método são indispensáveis, mas não a resposta ao que é irredutível a eles. Afirma que sabemos que não somos o "outro" (p. 226), mas também aprendemos através das ciências que não somos o eu ou transpa-

6 Website de Cayenne: doggery.org. Acesso em: 9 ago. 2020. 
rentemente presentes para o eu. A partir disso, com base em estudos de teóricos como Gregory Bateson (p. 237) e Alfred North Whitehead (p. 243), Haraway defende possibilidades de progressos semióticos multiespécies na libertação de um propósito de conhecimento transcendente. Haraway apresenta maneiras para pensar sobre domesticação e modos de cultivo de sociabilidade multiespécie. Mostra como o ato de brincar é uma atividade que potencializa laços afetivos e cognitivos entre os parceiros multiespécies. Além disso, é uma forma de abertura para proposições linguísticas, ou não, que vão além da mera funcionalidade.

No terceiro capítulo, intitulado "Espécies Emaranhadas”, Haraway trata dos fenômenos e dos problemas das criaturas que emergem no ambiente tecnocultural. Inicialmente discute sobre tecnologias no sentido de compostos vivos (p. 250), os quais podem funcionar como recintos ou dobras entre parceiros ativos (não só humanos) e materialidades. Em discussão sobre o assunto, ela apresenta sua análise semiótica multiespécie do programa televisivo Crittercam, onde problematiza os invólucros culturais e materiais que conectam animais e cientistas marinhos, câmeras, um grupo heterogêneo de equipamentos associados, a National Geographic Society, um programa popular sobre a natureza, sites e revistas científicas oceânicas.

Nesse capítulo ela também aborda as criaturas como construções sociais e culturais a partir do exame das composições multiespécies de caráter global e histórico. No caso Chicken Little (p. 265) Haraway, por exemplo, ela demonstra como o tráfico ilegal e a exploração de animais envolvem não apenas aves, trabalhadores humanos e maquinário industrial, mas a construção de culturas de variação espaço-temporal de transformação dos envolvidos e espécies elaboradas. E ainda, sob outra perspectiva, no caso dos gatos selvagens (p. 275) em que relações específicas e espécies situadas são moldadas em culturas tecnocientíficas de classe média, rurais ou suburbanas.

Em síntese, Haraway nos conduz à percepção de que assumir as contingências e as responsabilidades faz parte do caminho para nos tornarmos espécies companheiras. E que a atenção e o respeito para a materialidade semiótica dos seres, ambientes e, sobretudo, seus laços co-modeladores são imprescindíveis para os encontros multiespécies e o florescimento de mundos diversos. 


\section{Referências}

Deleuze, Gilles; Guattari, Félix. A thousand plateaus: capitalism and schizophrenia. Minneapolis: University of Minnesota Press, I987.

Gane, Nicholas. When we have never been human, what is to be done? Interview with Donna Haraway. Theory, Culture \& Society, 23 (7-8), p. I35I58, 2006.

HaRAwAY, Donna. A cyborg manifesto: science, technology, and socialistfeminism in the late twentieth century. In: Simians, cyborgs, and women: the reinvention of nature. New York, Routledge, I985, p. I49-I8I.

Primate visions: gender, race, and nature in the world of modern science. New York and London: Routledge, i989.

The companion species manifesto: dogs, people and significant otherness. Chicago: Prickly Paradigm Press, 2003.

When species meet. Posthumanities Series, v. 3, Cary Wolfe (ed.). Minneapolis: University of Minnesota Press, 2008.

MARX, Karl. Capital, v. I. New York: Vintage Books, I977. 